\title{
Subchronic Exposure to Cadmium Causes Persistent Changes in the Reproductive System in Female Wistar Rats
}

\author{
Marzenna Nasiadek $\mathbb{D}^{1},{ }^{1}$ Marian Danilewicz $\mathbb{D}^{2},{ }^{2}$ Michał Klimczak, ${ }^{1}$ Joanna Stragierowicz, ${ }^{1}$ \\ and Anna Kilanowicz ${ }^{1}$ \\ ${ }^{1}$ Department of Toxicology, Medical University of Lodz, Muszynskiego 1, 90-151 Lodz, Poland \\ ${ }^{2}$ Department of Pathology, Medical University of Lodz, Pomorska 251, 92-213 Lodz, Poland \\ Correspondence should be addressed to Marzenna Nasiadek; marzenna.nasiadek@umed.lodz.pl
}

Received 25 April 2019; Revised 28 September 2019; Accepted 11 November 2019; Published 18 December 2019

Guest Editor: Henrique Almeida

Copyright (C) 2019 Marzenna Nasiadek et al. This is an open access article distributed under the Creative Commons Attribution License, which permits unrestricted use, distribution, and reproduction in any medium, provided the original work is properly cited.

Cadmium (Cd) is an environmental toxicant and endocrine disruptor in humans and animals, and recent studies have illustrated that the uterus is exceedingly sensitive to Cd toxicity. The aim of the study was to investigate the influence of subchronic ( 90 days) oral Cd exposure in daily doses of $0.09-4.5 \mathrm{mg} / \mathrm{kg}$ b.w. on the balance of sex hormones by estimating estradiol $\left(\mathrm{E}_{2}\right)$ and progesterone (P) concentrations in the uterus and plasma in comparison with the effects of $17 \beta-\mathrm{E}_{2}$. Additionally, the uterine weight, histopathological changes in the uterus and ovaries, the regularity of the estrous cycle, Cd bioaccumulation in uterine tissue, and selected biochemical parameters of oxidative stress were determined. A long period of observation (three and six months following the administration period) was used to assess whether the existing effects are reversible. The lowest dose of Cd caused effects similar to $17 \beta-\mathrm{E}_{2}$ : an increase of $\mathrm{E}_{2}$ concentration in the uterus, endometrial epithelium thickness, and disturbed estrous cycle with estrus phase prolongation. The obtained results suggest that $\mathrm{Cd}$ causes nonlinear response. Higher doses of Cd caused a significant decrease in $\mathrm{E}_{2}$ concentration in the uterus and plasma, estrous cycle disturbances, endometrium atrophy, and structural damage in the ovaries. This dose additionally induces lipid peroxidation in the uterine tissues. It is noteworthy that a prolonged time of observation after terminating the exposure showed persistent changes in the concentration of $E_{2}$ in uterine tissue, as well as alterations in estrous cycle phases, and an increase in lipid peroxidation in the uterus. Moreover, significant positive correlations between the plasma $\mathrm{E}_{2}$ concentration and endometrial epithelium thickness in all studied groups were found. In summary, subchronic oral Cd exposure of female rats may result in impaired fertility processes.

\section{Introduction}

Cadmium $(\mathrm{Cd})$ is an important industrial and environmental pollutant. In addition, it should be taken into account that $\mathrm{Cd}$ pollution is global; hence, this metal has been placed 7 th on the list of substances that pose a potential threat to human health due to their known or suspected toxicity [1]. Cd is used for the plating of steel, as a plastic stabilizer, as an electrode material in nickel-cadmium batteries, and as a material in semiconductors. Mining, smelting, and industrial use have resulted in the increased bioaccessibility of $\mathrm{Cd}$ in the environment, and anthropogenic sources are the most significant threat to human health [2]. Although Cd is used in a variety of manufactured products, for most people in the general population the primary sources of exposure are food and smoking tobacco [2, 3]. Cigarette smoking contributes between two and four $\mu \mathrm{g}$ of Cd per pack. The European Food Safety Authority (EFSA) has estimated the average daily dietary exposure of $\mathrm{Cd}$ to be between 20.3 and $74.2 \mu \mathrm{g}$ /day per $70 \mathrm{~kg}$ person [4]. Specific groups at risk of consuming higher dietary $\mathrm{Cd}$ than is recognized as safe are children and vegetarians [5].

Women are thought to be at greater risk of increased $\mathrm{Cd}$ accumulation as the concentrations of $\mathrm{Cd}$ in the blood, tissue, and urine are higher than in males due to lower concentrations of iron [6-9]. In humans, Cd accumulates not only in the kidney and liver, but also in the reproductive organs [10-12]. To date, many in vivo studies indicate the toxic 
effects of $\mathrm{Cd}$ on female reproductive organs, including the endocrine system, the effects which seem to depend not only on the dose but also on the route of Cd administration [13-24]. However, the mechanism of Cd reproductive toxicity has not yet been elucidated completely, and there are still controversies with regard to the estrogen-like effect of this metal. Cd is listed as a metalloestrogen because of its ability to bind to the cellular estrogen receptor (ER) and hence mimic the actions of estrogens [25]. Johnson et al. [26] reported that $\mathrm{Cd}$ exposure in ovariectomized rats produced uterine hyperplasia, increased growth of the mammary glands, and the induction of hormone-regulated genes. Ali et al. [27] suggest that Cd exposure induces a limited spectrum of estrogenic responses in vivo and that, in certain targets, the effects of $\mathrm{Cd}$ might not be mediated via classical ER signaling through estrogen response element-regulated genes. Because of disturbed steroid hormone secretion, it is also suggested that the direct effect of $\mathrm{Cd}$ on the ovaries or the indirect effect of $\mathrm{Cd}$ on the hypothalamus-pituitarygonadal axis should not be excluded. It was proved in in vivo studies that $\mathrm{Cd}$ administration leads to histopathological alterations in the ovary (degeneration of the corpus luteum, damaged and less numerous oocytes, and degeneration of granulosa cells) and uterus (an increase in the luminal epithelial height and in the endometrial thickness) [24, 2830]. In addition, subacute $\mathrm{Cd}$ administration led to $\mathrm{Cd}$ accumulation and the induction of oxidative stress in rat ovaries and uterus $[29,31]$. The results of our previous work indicate that subacute (30-day) exposure to Cd leads to histopathological changes in the ovaries and in the uterus, as well as disturbances in the concentrations of circulating steroid hormones, suggesting an antiestrogenic effect, which was associated with abnormalities in the estrous cycle in female rats [24]. Despite that environmental exposure to Cd is lifelong, data on the subchronic or long-term effects of $\mathrm{Cd}$ on the uterus is still limited. Thus, the aim of the study was to investigate the subchronic effects of $\mathrm{Cd}$ on the female rat reproductive system-by estimating the balance of sex hormones based on estradiol $\left(\mathrm{E}_{2}\right)$ and progesterone $(\mathrm{P})$ concentrations in the uterus and plasma in comparison with the effects of $17 \beta-\mathrm{E}_{2}$. Additionally, the uterine weight, histopathological changes of the uterus and ovaries, estrous cyclicity, Cd bioaccumulation in uterine tissue, and selected biochemical parameters of oxidative stress were determined. In order to discover whether the existing effects are reversible, we used a long period of observation in the exposed females, i.e., three and six months after the subchronic $\mathrm{Cd}$ administration period, after which the same parameters were determined.

\section{Material and Methods}

2.1. Animal Selection, Care, and Drug Treatment. Adult female Wistar rats (12 weeks old) were kept in polypropylene cages at a controlled temperature of $22 \pm 1^{\circ} \mathrm{C}$ and relative humidity of $50-60 \%$ with free access to tap water and a diet low in phytoestrogen content (Ssniff R/M-H). The rats were allowed to acclimate for two weeks, during which the regularity of the estrous cycles was confirmed.
The regularly cycling rats were separated into three experimental groups (each $n=56$ ), A, B, and C, which were then divided into seven subgroups (each $n=8$ ). The experimental design and dose regiment is summarized in Figure 1. The four Cd subgroups (from each of the following groups: $\mathrm{A}, \mathrm{B}$, and $\mathrm{C}$ ) received Cd orally by gavage for 90 days $\left(\mathrm{CdCl}_{2}\right.$, Sigma-Aldrich, St. Louis MO, USA) at different daily doses of $0.09,0.9,1.8$, and $4.5 \mathrm{mg} / \mathrm{kg}$ b.w., which corresponded to $1 / 1000,1 / 100,1 / 50$, and $1 / 20 \mathrm{LD}_{50}(88 \mathrm{mg} / \mathrm{kg}$ b.w.) [32], respectively. The three control subgroups (from each of the following groups: A, B, and C) were administered distilled water (pure control), peanut oil (oil control), and $17 \beta-\mathrm{E}_{2}$ in a dose of $0.03 \mathrm{mg} / \mathrm{kg}$ b.w. (Sigma-Aldrich, St. Louis, MO, USA) dissolved in peanut oil (positive control). After 90 days of exposure, group A was sacrificed; however, groups B and C were subjected to three-month (90-day) and six-month (180-day) observation periods, respectively. The animals from the control subgroups received vehicle following the same protocol used for the rats exposed to $\mathrm{Cd}$. The daily water intake and feeding habits of all the animals were carefully observed throughout the experimental schedule. During and following the treatment, all animals were observed carefully for mortality, body weight, and gross behavioral changes. All procedures conducted on the rats were approved by the Local Animal Ethical Committee of the Medical University of Lodz (LKE 46/LB/481/2009; 14/LB481/DLZ/2012).

2.1.1. Euthanasia, Tissue Collection, and Preservation. The female rats which were in the estrus stage were weighed and underwent euthanasia after 90 days of exposure (group A), and after 90 days (group B) or 180 days (group C) of observation following a 90-day exposure. Blood samples were collected from all rats by heart puncture under light carbon dioxide anesthesia into Vacutainer tubes for metal analysis (S-Monovette, Sarstedt). The ovaries and the uterus were dissected out and weighed. For histological examination, part of the uterus and all of the ovaries were fixed in $10 \%$ formalin.

For Cd analysis, whole blood $(1 \mathrm{~mL})$ was kept in acidwashed cryotubes at $-80^{\circ} \mathrm{C}$, while the remaining part of the blood was centrifuged at $3000 \times \mathrm{g}\left(10 \mathrm{~min}, 4^{\circ} \mathrm{C}\right)$ to separate the plasma. Part of the uterus was stored at $-80^{\circ} \mathrm{C}$ in cryotubes for $\mathrm{Cd}$ analysis. The plasma for hormone analysis and biochemical assays (sex hormones and total antioxidant status (TAS) concentrations) was stored at $-20^{\circ} \mathrm{C}$.

2.2. Cd Concentration Assessment. The whole blood and uterus $\mathrm{Cd}$ concentrations were measured using GFAAS (Hitachi Z-8270) with the Zeeman-type background correction, autosampler, and pyrocoated tube. Earlier, the whole blood and uterus samples were digested with ultrapure $\mathrm{HNO}_{3}$, using a microwave digestion system (MARSXpress, CEM Corporation, USA). To determine Cd concentrations, samples were prepared in duplicate. For each series of analyses, internal quality controls were used (analyses of reference samples: Seronorm Whole Blood Level 1 (Sero, Norway) and Bovine liver 1577b (National Institute of Standards and Technology)). The analytical quality control was in the range of reference values. The limit of detection (LOD) for Cd 




FIgURE 1: Experimental model.

determined by GFAAS was $0.2 \mu \mathrm{g} / \mathrm{L}$ or $0.2 \mathrm{ng} / \mathrm{g}$ wet tissue. $\mathrm{Cd}$ concentrations in whole blood and uterine tissue were expressed as $\mu \mathrm{g} / \mathrm{L}$ or $\mu \mathrm{g} / \mathrm{g}$ wet tissue.

2.3. Estrous Cycle Assessment. The estrous cycle was determined by cytological examination of vaginal smears obtained for two consecutive weeks prior to conducting the experiments and two weeks before section. The stages of rat estrous cycle were classified as proestrus, estrus, metaestrus, and diestrus according to the presence, absence or proportions of vaginal smears of three cell types: cornified cells (keratinized), epithelial cells, and leukocytes. The estrous cycle duration was calculated as the number of days between the estrus and proestrus stage $[33,34]$.

2.4. Histopathological Examinations. Part of the uterus and ovaries were fixed in $10 \%$ formalin for $24 \mathrm{~h}$ and then embedded in paraffin blocks, sliced into $5 \mu \mathrm{m}$ sections, and stained with hematoxylin-eosin (H\&E) for the histopathological evaluation. The sections were examined under a light microscope (Olympus BX51; Olympus, Tokyo, Japan).

2.5. Measuring Endometrial Epithelium Thickness. The thickness of the epithelial layer was evaluated using a computer image analysis system consisting of a PC equipped with a Pentagram graphic tablet, an Indeo Fast card (frame grabber, true-color, real-time) produced by Indeo (Taiwan), and a color TV camera from Panasonic (Japan) coupled with a Carl Zeiss microscope (Germany). This system was programmed (MultiScan 18.03 software, produced by Computer Scanning Systems, Poland) to calculate the distance (semiautomatic function). In each case, measurements were performed in high-power monitor fields and then the mean endometrial epithelium thickness was calculated.

\subsection{Biochemical Analysis}

2.6.1. Plasma Sex Hormone Concentration. The plasma $\mathrm{E}_{2}$ and $\mathrm{P}$ concentrations were determined by an electrochemiluminescence method using a Roche Diagnostic kit on a Cobas 2601 analyzer (LOD: $\mathrm{E}_{2}=5 \mathrm{pg} / \mathrm{mL} ; \mathrm{P}=0.03 \mathrm{ng} / \mathrm{mL}$ ). The values reported are the sum of estradiol and estrone because chromatographic purification of the samples was not performed.

The concentrations of $\mathrm{E}_{2}$ and $\mathrm{P}$ in the rat tissue were determined using an ELISA kit according to the manufacturer's instructions, respectively: rat $\left(\mathrm{E}_{2}\right)$ ELISA kit-catalog No. 201-11-0175, SRB (China), and (P) ELISA kit-catalog No. CSB-E07282r Cusabio Biotech Co., Ltd, (Japan). The sensitivities of the kits were $\mathrm{E}_{2}=3.112 \mathrm{pg} / \mathrm{mL}$ and $\mathrm{P}=0.25$ $\mathrm{ng} / \mathrm{mL}$. The samples of uterus for hormone analysis were homogenized well to produce $10 \%$ homogenates in PBS and stored overnight at $-20^{\circ} \mathrm{C}$. For the assay of $\mathrm{E}_{2}$, the samples were centrifuged for $20 \mathrm{~min}$ at $2000-3000 \times \mathrm{g}$. For the assay of $\mathrm{P}$, after two freeze-thaw cycles were performed to break the cell membranes, the homogenate was centrifuged for $5 \mathrm{~min}$ at $5000 \times \mathrm{g}$ at $2-8^{\circ} \mathrm{C}$. The $\mathrm{E}_{2}$ and $\mathrm{P}$ assays in the supernatant were carried out immediately.

2.6.2. Determination of Plasma TAS. The major antioxidant defences in plasma include ascorbate, protein thiols, bilirubin, urate, and $\alpha$-tocopherol. Applying this method (TAS) allows to determine these major antioxidants in plasma. The plasma TAS was measured with a Ransel NX 2332 ready-made test (Randox Laboratories), according to the manufacturer's instructions. The TAS concentration was expressed as $\mathrm{mM}$.

2.6.3. Determination of Catalase (CAT) Activity in Uterus. The uterus tissues were rapidly excised and homogenized in 
an ice bath using phosphate-buffered saline (pH 7.4) with $0.01 \%$ digitonin using a Kika Labortechnik T-25 basic homogenizer. The homogenate was centrifuged at 10,000 $\times$ $\mathrm{g}$ for $30 \mathrm{~min}$ at $4^{\circ} \mathrm{C}$. CAT activity in the supernatant of the uterus homogenate was measured using a CAT 240 colorimetric assay kit for CAT activity (Applied Bioanalytical Labs) according to the manufacturer's instructions. CAT activity was expressed as U/mg protein. Protein concentrations in supernatants were determined according to Lowry et al. [35].

2.6.4. Determination of GSH in Uterus. The GSH concentration in the uterus $(10 \%$ homogenate in phosphate-buffered saline $\mathrm{pH}$ 8.0) was determined according to Sedlak and Lindsay [36]. This method allows to assay nonprotein sulfhydryl compounds (NPSH), the sum of cellular glutathione and cysteine. Glutathione exists in thiol-reduced (GSH) and disulfide-oxidized (GSSG) forms. The GSH accounts for more than $90 \%$ of total NPSH [37], while the GSSG content is less than $1 \%$ of GSH [38]. The standard curve was obtained by using GSH, hence the results were expressed as GSH concentration ( $\mu \mathrm{mol} / \mathrm{g}$ tissue).

2.6.5. Determination of MDA in Uterus. MDA concentrations, an indicator of free radical generation, which increases at the end of the lipid peroxidation, were estimated according to Uchiyama and Mihara [39]. The concentration of MDA was expressed as nmol/g tissue.

2.7. Statistical Analysis. All biochemical data were analyzed by STATISTICA software (StatSoft, Poland). We used the Kruskal-Wallis one-way analysis of variance followed by a pair-wise comparison of selected means with the MannWhitney $U$-test. We used Spearman's rank correlation $(r)$ to assess univariate associations.

In the estrous cycle, the statistical analysis was comprised of the following: (1) the mean length of the estrous cycle in the controls and the Cd-exposed females, and (2) the frequency of each of the four cycle phases. The one-way analysis of variance following Dunnet's test was used in the case of variance homogeneity, and the Kruskal-Wallis analysis of variance was followed by the nonparametric test in the case of heterogeneity. Frequency data were analyzed with the Fisher's exact probability test. The statistical significance was set at $p \leq 0.05$.

\section{Results}

During the whole administration time (90 days) and observation periods (three or six months) no changes in animal behavior or appearance were noted; all rats survived until the termination of the study. There were also no significant changes in feed and water intake during the Cd administration or observation periods (data not shown). Moreover, integral toxicity parameters, such as body weight, selected organs' (liver, kidneys, and uterus) absolute and relative weights, and weight gain were unchanged in all groups (Supplementary Table S1 and S2).
3.1. Cd Concentration. Subchronic per os administration of $\mathrm{Cd}$ at the range of doses used in this study resulted in a significant dose-dependent increase in whole blood $\mathrm{Cd}$ concentration (Cd-B), as depicted in Figure 2. The mean $\mathrm{Cd}-\mathrm{B}$ in rats from all pure control groups did not exceed $0.3 \mu \mathrm{g} / \mathrm{L}$. With the exception of the lowest $\mathrm{Cd}$ dose $(0.09 \mathrm{mg} / \mathrm{kg}$ b.w. $)$, significantly elevated Cd-B were maintained for both three and six months following the exposure. However, a decreasing trend in Cd-B could be observed in the postexposure period for all used doses (Figure 2). For the first three months of observation, the rate of Cd-B decrease was faster (about 10 times) than during the subsequent three months of observation (about twice). Only in the case of the lowest dose $(0.09 \mathrm{mg} / \mathrm{kg}$ b.w.) did the Cd-B concentration decrease about three times after three months following the exposure period.

Like the whole blood, the concentration of $\mathrm{Cd}$ in the uterus was also dose-dependent (Figure 3 ). In the case of the uterus, the mean increase in $\mathrm{Cd}$ concentration, after 90 days' administration with $\mathrm{Cd}$ doses of $0.09,0.9,1.8$, and $4.5 \mathrm{mg} / \mathrm{kg}$ b.w., was 15-, 80-, 320-, and 500-fold, respectively, compared to the control group. However, in contrast to $\mathrm{Cd}-\mathrm{B}$, all used doses caused a significant increase in Cd concentrations in this tissue, which was maintained at nearly the same concentration for up to six months after the end of the administration period. Moreover, in the examined females, a significant, strong correlation between the $\mathrm{Cd}-\mathrm{B}$ and $\mathrm{Cd}$ concentrations in uterine tissues was observed after 90 days of exposure $(r=0.98 ; p \leq 0.05)$ and after three $(r=0.92$; $p \leq 0.05)$ and six months following termination of the exposure $(r=0.96 ; p \leq 0.05)$.

3.2. Concentrations of Sex Hormones. Concentrations of selected sex hormones $\left(\mathrm{E}_{2}\right.$ and $\left.\mathrm{P}\right)$ and their ratio $\left(\mathrm{P} / \mathrm{E}_{2}\right)$, both in the plasma and in the uterus tissue, are presented in Figures 4 and 5. The $\mathrm{E}_{2}$ plasma concentration significantly decreased after administration of $\mathrm{Cd}$ in doses $0.9-4.5 \mathrm{mg} / \mathrm{kg}$ b.w. (Figure 4(a)), but this effect was not observed in the postexposure periods. In the case of the uterus, only the lowest dose $(0.09 \mathrm{mg} / \mathrm{kg}$ b.w. $)$ and the positive control caused a significant $\mathrm{E}_{2}$ concentration increase in contrast to the other Cd doses, where the opposite trend was observed (Figure 5(a)). However, after 90 and 180 days of observation, in almost all animals exposed to Cd, a diminished concentration of $E_{2}$ was noted (Figure 5(a)). In the positive control group, the remarkably higher concentration of $E_{2}$ noted at the end of the exposure lasted up to six months in the plasma and up to three months in the uterus (Figures 4(a) and 5(a)).

The concentration of $\mathrm{P}$ in plasma seems to be unaffected by $\mathrm{Cd}$ administration (Figure 4(b)). In the uterus, only exposure to the lowest dose resulted in a significant increase in $\mathrm{P}$ concentration (Figure 5(b)). For a better illustration of the disturbed hormonal homeostasis, a $\mathrm{P} / \mathrm{E}_{2}$ ratio was calculated (Figures 4(c) and 5(c)). As shown in the results from Figure 4(c), significant disturbances in the calculated ratio of hormones' concentrations $\left(\mathrm{P} / \mathrm{E}_{2}\right)$ in the plasma was observed only after 90 days of the exposure in the groups of rats administrated $\mathrm{Cd}$ at doses of $0.9-4.5 \mathrm{mg} / \mathrm{kg}$ b.w., which 




FIgure 2: Cadmium concentrations in blood (Cd-B) following 90-day oral exposure to $\mathrm{CdCl}_{2}$ or $17 \beta$-estradiol (positive control), at the 90-day and 180-day postexposure periods. $p \leq 0.05$ (a-vs. pure control group, b-vs. oil control, and $\mathrm{c}$-vs. positive control).

mainly result from a decrease of $\mathrm{E}_{2}$ concentration in the plasma of these females. However, in uterine tissue, significant changes were detected in the calculated ratio of $\mathrm{P} / \mathrm{E}_{2}$ hormones in all assessed groups, which persisted until termination of the observation, with the exception of the group administered the lowest dose, in which the changes were not statistically significant (Figure 5(c)).

3.3. Estrous Cycle. The results of the estrous cycle analysis after exposure to $\mathrm{Cd}$ are presented in Table 1 and in Supplementary Figures S1-S3. For better readability of the observed disorders, which often occur in individual rats and sometimes there was no statistical significance in the group observed, in the figures, they are presented for each female rat individually. The highest number of both extended cycles and different phase lengths was recorded after 90 days of exposure in almost all groups administered $\mathrm{Cd}$. The largest prolongation of the cycle length $(5.6 \pm 0.3$ days $)$ was noted in the positive control, which was caused by the prolongation of the estrus phase at the expense of the diestrus and proestrus phases. In the groups of female rats exposed to $\mathrm{Cd}$ in doses of $0.09-1.8 \mathrm{mg} / \mathrm{kg}$ b.w., a statistically significant prolongation of the cycle was also noted in $37.5-50 \%$ of the rats; however, it was conditioned not only by the estrus phase (doses of 0.09 and $1.8 \mathrm{mg} / \mathrm{kg}$ b.w.) but also by the diestrus phase (dose of $0.9 \mathrm{mg} / \mathrm{kg}$ b.w.). After the rats were administered the highest dose of Cd $(4.5 \mathrm{mg} / \mathrm{kg}$ b.w.), no significant increase in the duration of the cycle length was observed, but the individual phases, especially diestrus and proestrus, were significantly extended and shortened, respectively.

After both three and six months of postexposure observation, a significant prolongation of the cycle length among the exposed groups was maintained only at the lowest $\mathrm{Cd}$ dose $(0.09 \mathrm{mg} / \mathrm{kg}$ b.w.) among $25 \%$ and $37.5 \%$ of the rats, respectively. However, the statistically significant prolongation of the estrus phase was only observed after 180 days of the postexposure period (Supplementary Figure S3). 


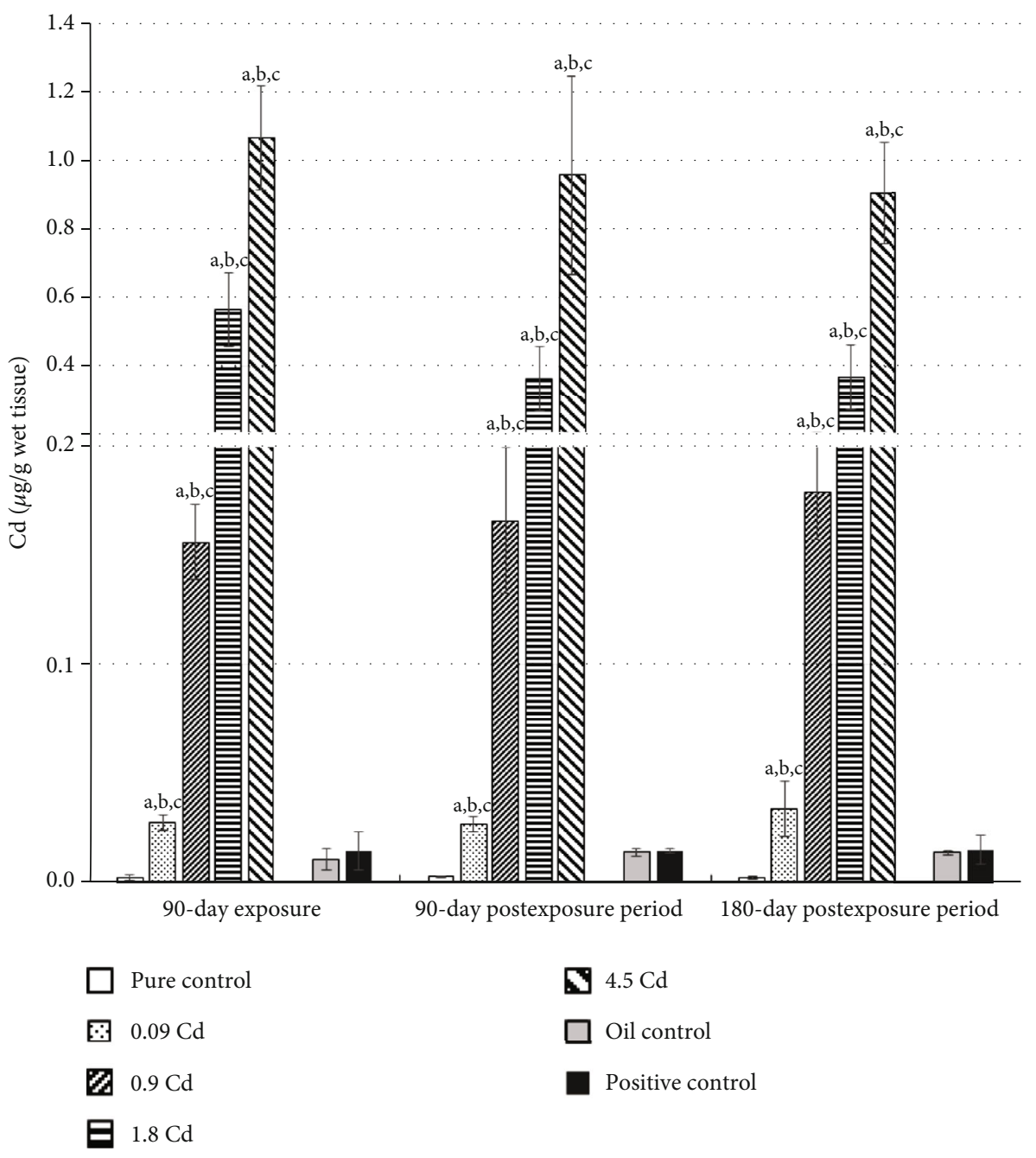

Figure 3: Cadmium concentrations in the uterus following 90-day oral exposure to $\mathrm{CdCl}_{2}$ or $17 \beta$-estradiol (positive control), at the 90 -day and 180-day postexposure periods. $p \leq 0.05$ (a-vs. pure control group, $\mathrm{b}-\mathrm{vs}$. oil control, and $\mathrm{c}-\mathrm{vs}$. positive control).

Administration of a higher dose $(0.9 \mathrm{mg} / \mathrm{kg}$ b.w.) both after 90 and 180 days of observation led only to a statistically significant extension of the estrus phase; however, it did not lead to significant changes in the duration of the whole cycle length (Supplementary Figures S2 and S3). In the positive control, no changes were noted in the estrous cycle length after six months of observation (Table 1). Nevertheless, in individual females, estrus and diestrus phase prolongation and shortening of the proestrus phase, especially after six months was observed (Supplementary Figure S3).

3.4. Endometrial Epithelium Thickness. Morphometric analysis during the estrus stage showed that $\mathrm{Cd}$ administered orally $(0.09,0.9,1.8$, and $4.5 \mathrm{mg} / \mathrm{kg} \mathrm{b.w.)}$ for 90 days induced a significantly increased thickness of the epithelial layer only after the smallest dose when compared to the pure control group (Table 2). Similar endometrium changes with increased glands in the uterus in the group of females treated with $17 \beta-\mathrm{E}_{2}$ were observed. These changes might suggest endometrial hyperplasia. Furthermore, the increase in endometrial epithelium thickness (1.6-fold) was detected in comparison to the oil and pure control groups, which persisted for six months following the termination of exposure to $17 \beta-\mathrm{E}_{2}$ (Table 2 and Figures $6(\mathrm{~g})$ and $(\mathrm{h})$ ). In contrast, after the administration of higher doses of $\mathrm{Cd}$, we observed a noticeable endometrium atrophy (a thin epithelial layer and not numerous glands), especially after a 180-day postexposure period, (Figures 6(c) and (d)) resulting from a decrease in $\mathrm{E}_{2}$, both in the plasma and in uterine tissue, confirmed by a significant correlation coefficient between the concentration of $\mathrm{E}_{2}$ in the plasma and endometrial epithelium thickness in all examined groups: $r=0.51(p \leq 0.05)$ for the exposure period (group A), $r=0.54(p \leq 0.05)$ after three months of observation (group B), and $r=0.71(p \leq 0.01)$ for the six-month observation period (group C) (Figure 7).

3.5. Ovary Histology. The control group demonstrated a normal basic structure of rat ovaries, usually containing a corpus luteum and all developmental stages of follicles (Figure $8(\mathrm{a})$ ). The Cd-exposed group ( $4.5 \mathrm{mg} / \mathrm{kg}$ b.w.) showed histopathological alterations in the ovary: degeneration of the 


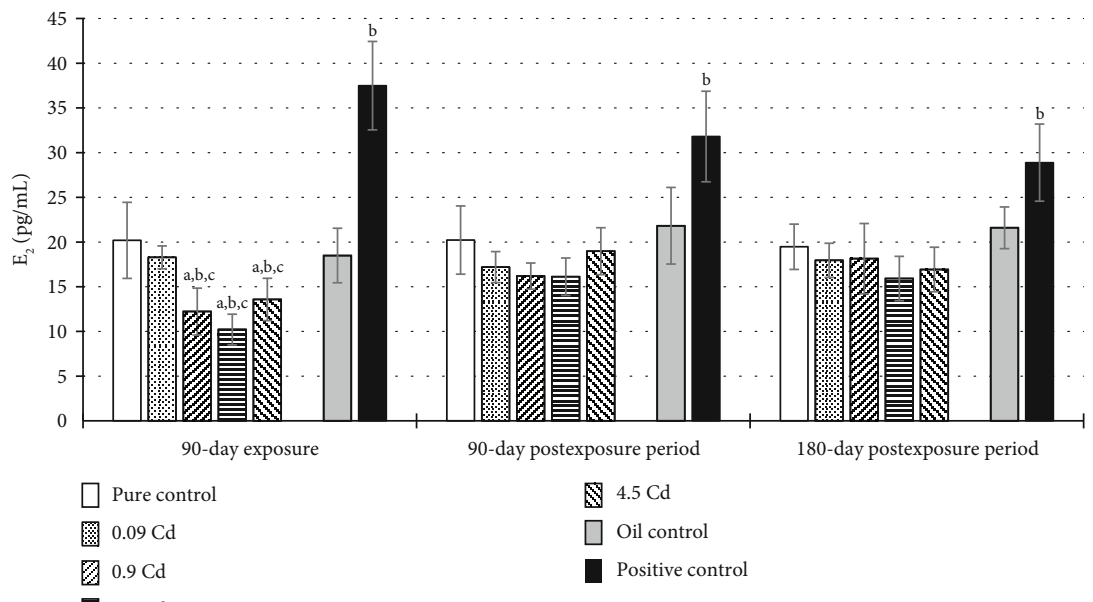

(a)



(b)

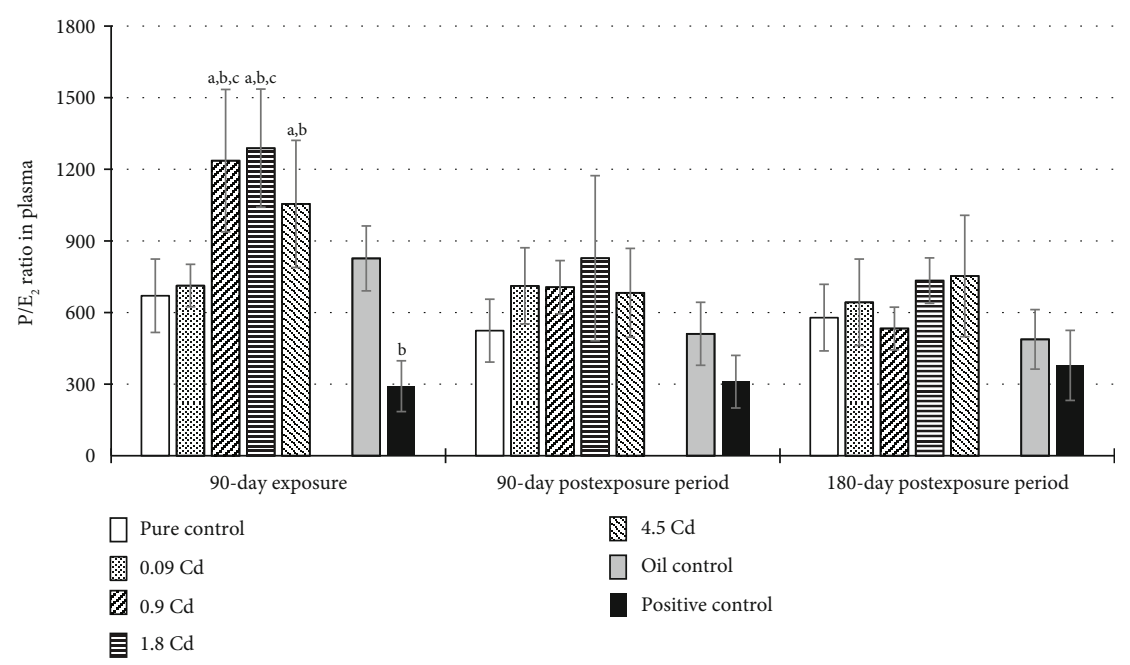

(c)

Figure 4: $\mathrm{E}_{2}$ (a) and $\mathrm{P}(\mathrm{b})$ concentrations and the ratio of $\mathrm{P} / \mathrm{E}_{2}$ (c) in plasma following 90-day oral exposure to $\mathrm{CdCl}_{2}$ or $17 \beta$-estradiol (positive control), at the 90-day and 180-day postexposure periods. $p \leq 0.05$ (a-vs. pure control group, b-vs. oil control, and c-vs. positive control). 




(a)



(b)



(c)

Figure 5: $\mathrm{E}_{2}$ (a) and $\mathrm{P}(\mathrm{b})$ concentrations and the ratio of $\mathrm{P} / \mathrm{E}_{2}(\mathrm{c})$ in uterine tissue following 90 -day oral exposure to $\mathrm{CdCl} \mathrm{l}_{2}$ or $17 \beta$-estradiol (positive control), at the 90-day and 180-day postexposure periods. $p \leq 0.05$ (a-vs. pure control group, b-vs. oil control, and c-vs. positive control). 
TABLE 1: Cycle phases and all cycle lengths following oral, subchronic $\mathrm{CdCl}_{2}$, or $17 \beta$-estradiol (positive control) exposure and 90- and 180day postexposure periods in comparison to controls.

\begin{tabular}{|c|c|c|c|c|c|c|c|}
\hline \multirow{2}{*}{ Treatment } & \multirow{2}{*}{ Dose (mg/kg b.w.) } & \multicolumn{4}{|c|}{ Phase length (days) } & \multirow{2}{*}{ Cycle length (days) } & \multirow{2}{*}{ No. of extended cycles } \\
\hline & & Proestrus & Estrus & Metaestrus & Diestrus & & \\
\hline \multicolumn{8}{|c|}{ Group A (90-day exposure) } \\
\hline Pure control & 0 & $1.8 \pm 0.1$ & $2.8 \pm 0.2$ & $2.6 \pm 0.1$ & $4.7 \pm 0.2$ & $4.3 \pm 0.1$ & 0 \\
\hline $\mathrm{Cd}$ & 0.09 & $1.2 \pm 0.1^{\mathrm{a}}$ & $4.6 \pm 1.0^{\mathrm{a}}$ & $1.9 \pm 0.3^{\mathrm{a}}$ & $4.6 \pm 0.7$ & $5.4 \pm 0.8^{\mathrm{a}}$ & 4 \\
\hline $\mathrm{Cd}$ & 0.9 & $1.8 \pm 0.2$ & $2.9 \pm 0.2$ & $2.2 \pm 0.2$ & $5.1 \pm 0.2^{\mathrm{a}}$ & $4.7 \pm 0.2^{\mathrm{a}}$ & 3 \\
\hline $\mathrm{Cd}$ & 1.8 & $1.8 \pm 0.2$ & $3.4 \pm 0.2^{\mathrm{a}}$ & $2.3 \pm 0.2$ & $4.4 \pm 0.2$ & $4.9 \pm 0.3^{\mathrm{a}}$ & 3 \\
\hline $\mathrm{Cd}$ & 4.5 & $1.4 \pm 0.1^{\mathrm{a}}$ & $2.8 \pm 0.2$ & $2.6 \pm 0.1$ & $5.2 \pm 0.2^{\mathrm{a}}$ & $4.5 \pm 0.3$ & 4 \\
\hline Oil control & 0 & $2.3 \pm 0.1$ & $2.6 \pm 0.1$ & $2.9 \pm 0.2$ & $4.3 \pm 0.2$ & $3.9 \pm 0.2$ & 0 \\
\hline Positive control & 0.03 & $1.4 \pm 0.1^{\mathrm{a}}$ & $4.6 \pm 0.4^{\mathrm{a}}$ & $2.3 \pm 0.2$ & $3.7 \pm 0.3^{\mathrm{a}}$ & $5.6 \pm 0.3^{\mathrm{a}}$ & 5 \\
\hline \multicolumn{8}{|c|}{ Group B (90-day exposure and 90-day postexposure periods) } \\
\hline Pure control & 0 & $1.7 \pm 0.1$ & $2.3 \pm 0.1$ & $2.8 \pm 0.2$ & $4.3 \pm 0.2$ & $3.8 \pm 0.1$ & 0 \\
\hline $\mathrm{Cd}$ & 0.09 & $1.7 \pm 0.1$ & $1.9 \pm 0.3^{\mathrm{a}}$ & $2.6 \pm 0.3$ & $4.8 \pm 0.4$ & $4.8 \pm 0.5^{\mathrm{a}}$ & 2 \\
\hline $\mathrm{Cd}$ & 0.9 & $1.6 \pm 0.1$ & $2.9 \pm 0.2^{\mathrm{a}}$ & $2.2 \pm 0.2^{\mathrm{a}}$ & $4.0 \pm 0.2$ & $4.1 \pm 0.1$ & 0 \\
\hline $\mathrm{Cd}$ & 1.8 & $1.6 \pm 0.1$ & $2.6 \pm 0.2$ & $2.6 \pm 0.1$ & $4.1 \pm 0.1$ & $4.0 \pm 0.1$ & 0 \\
\hline $\mathrm{Cd}$ & 4.5 & $1.8 \pm 0.2$ & $2.4 \pm 0.2$ & $2.8 \pm 0.2$ & $4.0 \pm 0.2$ & $3.9 \pm 0.1$ & 0 \\
\hline Oil control & 0 & $1.6 \pm 0.1$ & $2.3 \pm 0.2$ & $2.9 \pm 0.2$ & $4.1 \pm 0.2$ & $4.0 \pm 0.1$ & 0 \\
\hline Positive control & 0.03 & $1.6 \pm 0.1$ & $2.2 \pm 0.1$ & $2.7 \pm 0.2$ & $4.4 \pm 0.1$ & $4.1 \pm 0.1$ & 0 \\
\hline \multicolumn{8}{|c|}{ Group C (90-day exposure and 180-day postexposure periods) } \\
\hline Pure control & 0 & $1.6 \pm 0.1$ & $2.8 \pm 0.1$ & $3.1 \pm 0.3$ & $4.4 \pm 0.1$ & $4.1 \pm 0.1$ & 0 \\
\hline $\mathrm{Cd}$ & 0.09 & $1.5 \pm 0.3$ & $4.9 \pm 0.9^{\mathrm{a}}$ & $2.7 \pm 0.3$ & $2.9 \pm 0.4^{\mathrm{a}}$ & $5.3 \pm 0.9^{\mathrm{a}}$ & 3 \\
\hline $\mathrm{Cd}$ & 0.9 & $1.6 \pm 0.2$ & $4.1 \pm 0.6^{\mathrm{a}}$ & $2.8 \pm 0.2$ & $3.5 \pm 0.3^{\mathrm{a}}$ & $4.3 \pm 0.3$ & 1 \\
\hline $\mathrm{Cd}$ & 1.8 & $1.6 \pm 0.1$ & $2.8 \pm 0.1$ & $3.4 \pm 0.1$ & $4.2 \pm 0.1$ & $4.0 \pm 0.1$ & 0 \\
\hline $\mathrm{Cd}$ & 4.5 & $1.8 \pm 0.1$ & $2.8 \pm 0.1$ & $3.6 \pm 0.3$ & $3.9 \pm 0.3$ & $4.2 \pm 0.1$ & 0 \\
\hline Oil control & 0 & $1.4 \pm 0.1$ & $2.8 \pm 0.1$ & $3.2 \pm 0.2$ & $4.7 \pm 0.2$ & $4.1 \pm 0.1$ & 0 \\
\hline Positive control & 0.03 & $1.4 \pm 0.1$ & $2.9 \pm 0.1$ & $3.3 \pm 0.2$ & $4.1 \pm 0.2$ & $4.3 \pm 0.2$ & 1 \\
\hline
\end{tabular}

All values are expressed as means $\pm \operatorname{SEM}(n=8)$. ${ }^{\text {a }}$ ignificantly different from pure control $(p \leq 0.05)$.

TABLE 2: Endometrial epithelium thickness $(\mu \mathrm{m})$ after subchronic oral exposure to $\mathrm{CdCl}_{2}$ or $17 \beta$-estradiol $\left(\mathrm{E}_{2}\right)$ exposure and 90 - and 180 -day postexposure periods in comparison to controls.

\begin{tabular}{|c|c|c|c|c|c|c|c|}
\hline \multirow{2}{*}{ Groups } & \multicolumn{7}{|c|}{ Endometrial epithelium thickness $(\mu \mathrm{m})$} \\
\hline & Pure control & $0.09 \mathrm{mgCd} / \mathrm{kg}$ & $0.9 \mathrm{mgCd} / \mathrm{kg}$ & $1.8 \mathrm{mgCd} / \mathrm{kg}$ & $4.5 \mathrm{mgCd} / \mathrm{kg}$ & Oil control & Positive control \\
\hline A-90-day exposure & $19.2 \pm 2.2$ & $27.0 \pm 3.1^{\mathrm{a}, \mathrm{c}}$ & $21.7 \pm 3.6^{c}$ & $20.1 \pm 3.1^{c}$ & $24.5 \pm 6.3^{c}$ & $21.9 \pm 3.3$ & $36.4 \pm 2.5^{\mathrm{b}}$ \\
\hline B-90-day postexposure period & $21.8 \pm 4.3$ & $21.9 \pm 1.9^{c}$ & $19.4 \pm 2.1^{\mathrm{c}}$ & $17.9 \pm 2.1^{\mathrm{c}}$ & $19.1 \pm 2.9^{c}$ & 21.80 & $34.8 \pm 2.5^{\mathrm{b}}$ \\
\hline C-180-day postexposure period & $21.7 \pm 1.7$ & $19.6 \pm 1.3^{\mathrm{c}}$ & $18.9 \pm 2.5^{\mathrm{c}}$ & $17.1 \pm 1.7^{\mathrm{a}, \mathrm{b}, \mathrm{c}}$ & $16.5 \pm 1.6^{\mathrm{a}, \mathrm{b}, \mathrm{c}}$ & $22.5 \pm 2.1$ & $33.8 \pm 4.1^{\mathrm{b}}$ \\
\hline
\end{tabular}

All values are expressed as mean $\pm \mathrm{SD}$. ${ }^{\mathrm{a}} p \leq 0.05$, significantly different from pure control animals. ${ }^{\mathrm{b}} p \leq 0.0$, significantly different from oil control. ${ }^{\mathrm{c}} p \leq 0.05$, significantly different from positive control.

corpus luteum and damaged and less numerous oocytes (Figures 8(b) and 8(c)). In the positive control, no degenerative changes in the ovaries were reported (Figure $8(d)$ ).

3.6. Oxidative Stress Parameters. Administration of $\mathrm{Cd}$ at the two highest doses ( 1.8 and $4.5 \mathrm{mg} / \mathrm{kg}$ b.w.) results in a significant rise of MDA concentration in the uterus (Table 3), but this effect persisted for the whole observation period following the exposure (up to six months) only after the highest dose $(4.5 \mathrm{mg} / \mathrm{kg}$ b.w.). The same dose also affects the activity of the uterine CAT causing a significant decrease (around 25\% compared to the pure control), but only just after the administration period. On the other hand, no changes in the concentration of GSH in this tissue were observed throughout all studied doses and periods. In the case of TAS, only the administration of $\mathrm{E}_{2}$ caused a remarkable increase of TAS in the plasma after the termination of exposure (Table 3). However, such effect was not noted in either observation periods or in the case of Cd exposure. 




(a)

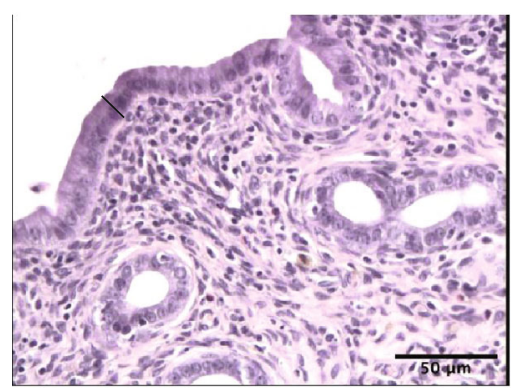

(c)

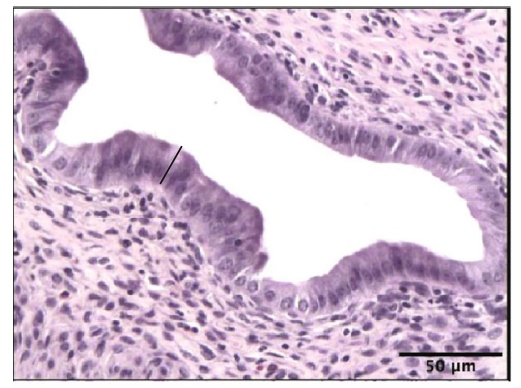

(e)

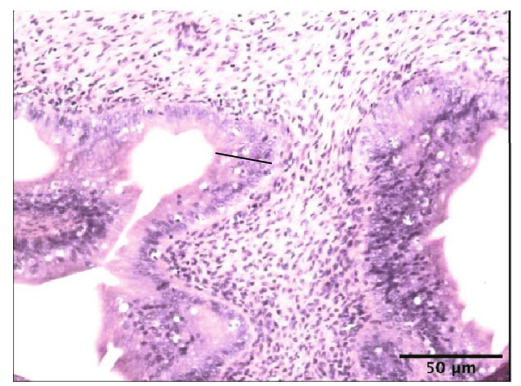

(g)



(b)

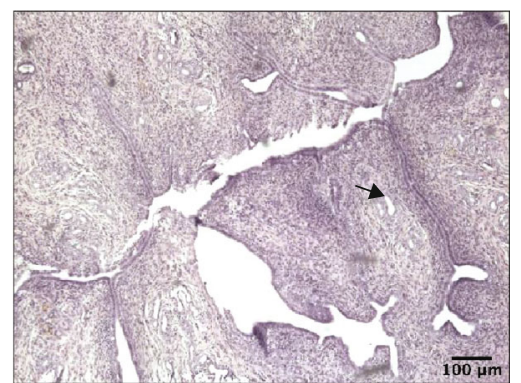

(d)



(f)

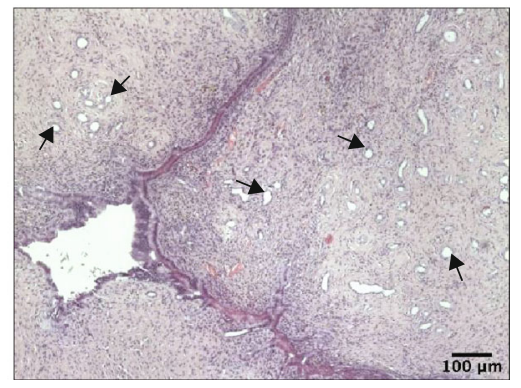

(h)

Figure 6: Effect of $\mathrm{CdCl}_{2}$ on uterine histology. Photomicrographs of uterine sections stained with hematoxylin and eosin from rats after a 180-day postexposure period (magnification: $\times 200$ and $\times 40)$. ( $\mathrm{a}$ and $\mathrm{b}$ ) Sections from the uteri of pure control rats. A thick epithelial layer is seen as well as many glands. (c) Sections from the uteri of the Cd group ( $4.5 \mathrm{mgCd} / \mathrm{kg}$ ). The epithelial layer is thin and contains a small number of the cells. (d) Sections from the uteri of the Cd group $(4.5 \mathrm{mgCd} / \mathrm{kg})$. The epithelial layer is thin, and the glands are not numerous. (e and f) Sections from the uteri of oil control rats. The epithelial layer is similar to that of the pure control rats. (g) Sections from the uteri of the $17 \beta$-estradiol group $\left(0.03 \mathrm{mgE}_{2} / \mathrm{kg}\right)$. Notice the increased thickness of the epithelial layer. (h) Sections from the uteri of the $17 \beta$-estradiol group $\left(0.03 \mathrm{mgE}_{2} / \mathrm{kg}\right)$. Numerous uterine glands are seen. Black bars represent epithelial thickness; arrows-uterine gland.

\section{Discussion}

There is a growing fear that a lifetime exposure to xenobiotics, which disturb hormonal homeostasis, may cause permanent change in the functioning of the organism, particularly in the reproductive system. Studies on the xenoestrogenicity of $\mathrm{Cd}$ conducted so far are ambiguous; some of them indicate its estrogenic activity [21, 25, 26, 40], while others show an antiestrogenic effect [21, 41, 42]. In the current study, to assess the estrogenic-like effect of $\mathrm{Cd}$ 




(a)

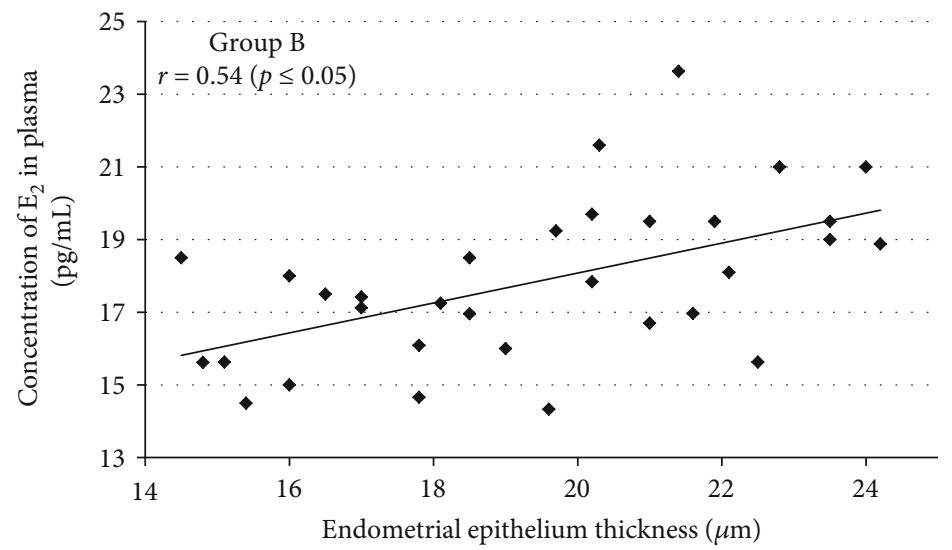

(b)

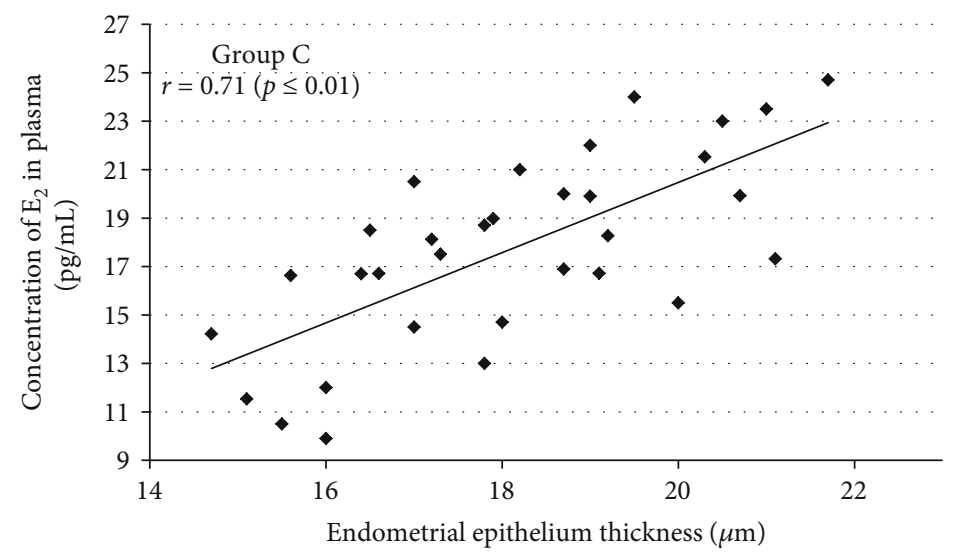

(c)

Figure 7: Association between plasma $\mathrm{E}_{2}$ concentration and endometrial epithelium thickness in Cd-exposed rats from group A (90-day exposure) (a); group B (90-day exposure and 90-day postexposure periods) (b); and group C (90-day exposure and 180-day postexposure periods) (c).

in female rats, we applied a 90-day Cd exposure model with a long observation period (up to six months) of exposed animals compared to control groups, including a positive control. We used per os administration, because this route is consistent with the general population's exposure to this metal. Average daily Cd intakes in European countries have been estimated between 0.00029 and $0.00106 \mathrm{mg} / \mathrm{kg}$ [4]. The lowest daily dose of Cd adopted in this study $(0.09 \mathrm{mg} / \mathrm{kg}$ b.w.) was similar to a lower level of general population envi- ronmental exposure $[43,44]$. In our study, Cd-B in rats exposed to $0.09 \mathrm{mg} / \mathrm{kg}$ b.w. for 90 days were similar to those observed in smokers in the general population [2]. Cd-B in long-term Cd exposure is thought to be a good indicator of its internal dose and accumulation, not only in the kidney (the target organ) but also in other soft tissues, including the uterus $[45,46]$. The results obtained both in this study and in our previous studies (30-day administration of $\mathrm{Cd}$ to female rats) confirm the relationship between $\mathrm{Cd}-\mathrm{B}$ and 


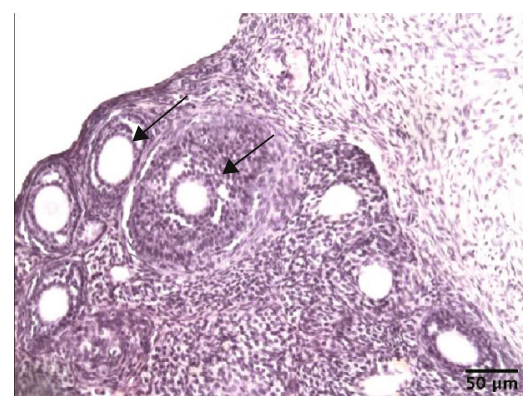

(a)

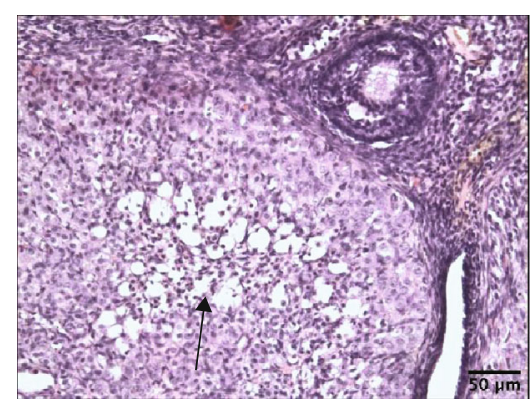

(c)

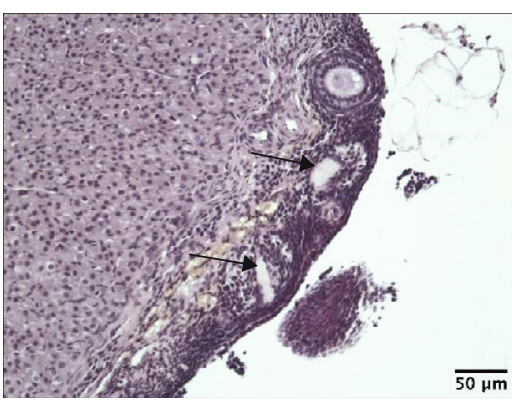

(b)

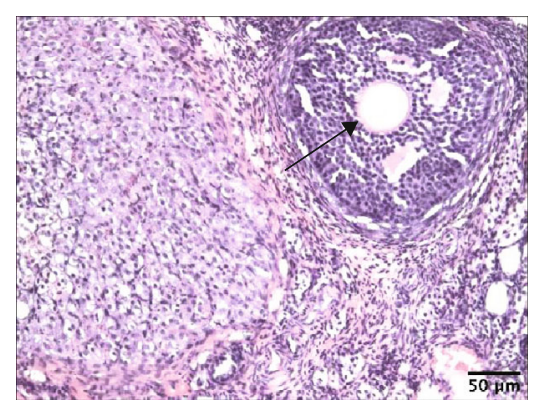

(d)

FIGURE 8: Effect of $\mathrm{CdCl}_{2}$ on ovary histology. Photomicrographs of ovary sections stained with hematoxylin and eosin (magnification: $\times 100$ ) from rats after a 180-day postexposure period. (a) Sections from the ovaries of pure control rats. Notice numerous oocytes (arrows). (b) Sections from the ovaries of the Cd group $(4.5 \mathrm{mg} \mathrm{Cd} / \mathrm{kg})$. The oocytes are scanty and two of them show degenerative changes (arrows). (c) Sections from the ovaries of the Cd group ( $4.5 \mathrm{mgCd} / \mathrm{kg}$ ). Arrow points-degenerative changes of corpus luteum. (d) Sections from the ovaries of the $17 \beta$-estradiol group $\left(0.03 \mathrm{mg} \mathrm{E}_{2} / \mathrm{kg}\right)$. Corpus luteum and big follicle are seen (arrow-big follicle).

Cd uterus concentration [24]. After a 90-day administration of $\mathrm{Cd}$, its concentration in the uterus increased in a dose-dependent manner and was about three times higher than that after a 30-day administration [24]. Moreover, Cd concentrations in the uterus six months after terminating the exposure were virtually at the same level as at the end of the administration period. Cd bioaccumulation in the uterine tissue was confirmed by numerous studies among smoking and nonsmoking women $[11,12,46]$. The health implications of $\mathrm{Cd}$ bioaccumulation in reproductive organs are still not well known.

$\mathrm{Cd}$ action as a metalloestrogen seems to depend not only on the level of exposure but also on its duration. While the administration of the lowest dose of Cd $(0.09 \mathrm{mg} / \mathrm{kg}$ b.w.) caused estrogenic-like effects, in female rats which were administered higher doses, antiestrogenic effects were observed. The estrogenic effects of the lowest Cd dose were expressed by firstly, significantly higher $\mathrm{E}_{2}$ concentrations in the uterine tissue which correlated with the endometrial epithelium thickness, and secondly, by the prolongation of the estrus stage in the estrous cycle, like in positive control receiving $17 \beta-\mathrm{E}_{2}$. An abnormal cycle was maintained for up to six months after the termination of the administration.

Uterus weight is one of the accepted endpoints useful in estrogenicity assessment of xenobiotics [47, 48]. Although changes in the endocrine profile or thickness of the epithelial endometrium may affect the weight of the uterus, in our study, the wet weight of the uterus was not significantly different compared to the pure control. Ali et al. [27] did not detect any changes in the wet weight of the uterus either, but they did notice an increase in the uterine luminal epithelium in mice receiving $\mathrm{Cd}$ in doses of 50 and $500 \mu \mathrm{g} / \mathrm{kg}$ b.w. Similarly, no changes in uterine weight due to Cd have been described in other studies [21, 49]; however, Johnson et al. [26] showed a significant increase in uterine weight in rats after a single i.p. injection of $\mathrm{Cd}$ at $5 \mu \mathrm{g} / \mathrm{kg}$ b.w.

The mechanism of the estrogenic action of $\mathrm{Cd}$ in the uterus is thought to be associated with the ER. Stoica et al. [25] suggest that $\mathrm{Cd}$ ions can activate the ER by creating high-affinity interactions with the hormone receptor binding domain. Fechner et al. [50] revealed that Cd interacts with the ligand binding domain (LBD) of the ER $\alpha$ and affects the conformation of the receptor. However, the binding event, as well as the induced conformation change, greatly depends on the accessibility of the cysteine tails in the LBD. Kluxen et al. [51] showed that Cd exerts estrogen-like effects and modulates aryl hydrocarbon receptor (AhR) expression and that of AhR target genes. There are also studies indicating that $\mathrm{Cd}$ does not activate classical estrogen signaling in the uterus but interferes with its pathway [27].

The fact that the estrogen response induced by Cd is dosedependent seems to be confirmed by in vitro studies. For instance, Denier et al. [52] demonstrated on yeast cells that $\mathrm{Cd}$ in low concentrations enhanced the estrogenic response due to the interaction of $\mathrm{E}_{2}$ with $\mathrm{ER}$. Importantly, in high concentrations, $\mathrm{Cd}$ was cytotoxic to yeast cells. The dosedependent effect of $\mathrm{Cd}$ was also observed in our study. The administration of $\mathrm{Cd}$ at high doses $(0.9-4.5 \mathrm{mg} / \mathrm{kg}$ b.w.) to female rats led to a decrease in $\mathrm{E}_{2}$ concentration in both 
TABLE 3: Oxidative stress biomarkers in rats after oral exposure to $\mathrm{CdCl}_{2}$ or $17 \beta$-estradiol (positive control) exposure and 90 - and 180 -day postexposure periods in comparison to controls.

\begin{tabular}{|c|c|c|c|c|c|}
\hline Treatment & $\begin{array}{c}\text { Doses } \\
\text { (mg/kg b.w.) }\end{array}$ & $\begin{array}{c}\text { TAS in plasma } \\
(\mathrm{mM})\end{array}$ & $\begin{array}{l}\text { GSH in uterus } \\
(\mu \mathrm{mol} / \mathrm{g})\end{array}$ & $\begin{array}{l}\text { CAT in uterus } \\
\text { (U/mg protein) }\end{array}$ & $\begin{array}{c}\text { MDA in uterus } \\
(\mathrm{nmol} / \mathrm{g})\end{array}$ \\
\hline \multicolumn{6}{|c|}{ Group A (90-day exposure) } \\
\hline Pure control & 0 & $1.16 \pm 0.09$ & $1.37 \pm 0.32$ & $8.66 \pm 0.96$ & $62.3 \pm 6.80$ \\
\hline $\mathrm{Cd}$ & 0.09 & $1.11 \pm 0.09$ & $1.47 \pm 0.46$ & $11.0 \pm 2.10$ & $80.2 \pm 7.05$ \\
\hline $\mathrm{Cd}$ & 0.9 & $1.08 \pm 0.04$ & $1.84 \pm 0.18$ & $12.3 \pm 1.54$ & $71.0 \pm 14.2$ \\
\hline $\mathrm{Cd}$ & 1.8 & $1.02 \pm 0.07$ & $1.20 \pm 0.41$ & $8.71 \pm 0.89$ & $84.7 \pm 4.25^{\mathrm{a}}$ \\
\hline $\mathrm{Cd}$ & 4.5 & $0.88 \pm 0.15$ & $1.53 \pm 0.40$ & $6.61 \pm 0.60^{\mathrm{a}, \mathrm{b}, \mathrm{c}}$ & $98.1 \pm 5.13^{\mathrm{a}, \mathrm{b}, \mathrm{c}}$ \\
\hline Oil control & 0 & $0.95 \pm 0.11$ & $1.80 \pm 0.10$ & $8.99 \pm 1.68$ & $61.8 \pm 3.52$ \\
\hline Positive control & 0.03 & $1.61 \pm 0.60^{b}$ & $1.56 \pm 0.33$ & $7.99 \pm 1.53$ & $70.0 \pm 8.52$ \\
\hline \multicolumn{6}{|c|}{ Group B (90-day exposure and 90-day postexposure periods) } \\
\hline Pure control & 0 & $1.04 \pm 0.09$ & $1.46 \pm 0.31$ & $9.02 \pm 1.60$ & $65.2 \pm 11.30$ \\
\hline $\mathrm{Cd}$ & 0.09 & $1.01 \pm 0.06$ & $1.24 \pm 0.21$ & $9.88 \pm 1.82$ & $74.5 \pm 10.92$ \\
\hline $\mathrm{Cd}$ & 0.9 & $1.00 \pm 0.03$ & $1.14 \pm 0.19$ & $11.0 \pm 1.54$ & $74.8 \pm 14.64$ \\
\hline $\mathrm{Cd}$ & 1.8 & $0.96 \pm 0.07$ & $1.32 \pm 0.20$ & $7.89 \pm 1.15$ & $72.9 \pm 9.07$ \\
\hline $\mathrm{Cd}$ & 4.5 & $0.93 \pm 0.08$ & $1.29 \pm 0.05$ & $7.25 \pm 1.61$ & $94.6 \pm 19.50^{\mathrm{a}}$ \\
\hline Oil control & 0 & $1.05 \pm 0.06$ & $1.41 \pm 0.12$ & $9.56 \pm 1.98$ & $67.0 \pm 5.04$ \\
\hline Positive control & 0.03 & $1.18 \pm 0.06$ & $1.61 \pm 0.54$ & $10.2 \pm 1.63$ & $68.9 \pm 9.02$ \\
\hline \multicolumn{6}{|c|}{ Group C (90-day exposure and 180-day postexposure periods) } \\
\hline Pure control & 0 & $1.02 \pm 0.08$ & $1.14 \pm 0.24$ & $9.66 \pm 1.36$ & $60.5 \pm 5.85$ \\
\hline $\mathrm{Cd}$ & 0.09 & $0.95 \pm 0.07$ & $1.25 \pm 0.29$ & $9.98 \pm 1.95$ & $58.2 \pm 13.90$ \\
\hline $\mathrm{Cd}$ & 0.9 & $0.98 \pm 0.04$ & $1.08 \pm 0.12$ & $10.6 \pm 1.83$ & $71.6 \pm 11.08$ \\
\hline $\mathrm{Cd}$ & 1.8 & $0.96 \pm 0.09$ & $0.99 \pm 0.08$ & $9.21 \pm 1.39$ & $75.3 \pm 5.33$ \\
\hline $\mathrm{Cd}$ & 4.5 & $0.95 \pm 0.10$ & $1.25 \pm 0.49$ & $8.98 \pm 1.65$ & $92.5 \pm 7.10^{\mathrm{a}, \mathrm{b}, \mathrm{c}}$ \\
\hline Oil control & 0 & $1.02 \pm 0.06$ & $1.21 \pm 0.24$ & $10.0 \pm 0.91$ & $64.9 \pm 6.93$ \\
\hline Positive control & 0.03 & $1.16 \pm 0.09$ & $1.15 \pm 0.25$ & $11.1 \pm 1.66$ & $62.7 \pm 3.96$ \\
\hline
\end{tabular}

All values are expressed as mean $\pm \mathrm{SD}$. ${ }^{\mathrm{a}} p \leq 0.05$, significantly different from control pure animals. ${ }^{\mathrm{b}} p \leq 0.05$, significantly different from oil control, ${ }^{c} p \leq 0.05$, significantly different from positive control.

plasma and uterine tissue. Although the effect of lowering $\mathrm{E}_{2}$ concentrations in plasma by Cd exposure has been previously described $[18,19,22]$, the same effect in the uterine tissue is, according to our knowledge, described here for the first time.

Disorders in $\mathrm{E}_{2}$ secretion may have various causes, including, for example, ovary damage, which was observed in this study and was expressed as, among others, degeneration of the corpus luteum, damaged and less numerous oocytes, and degeneration of the granulosa cells. These effects are in agreement with the literature [20, 28-30]. Structural damage to the ovary and disturbed $\mathrm{E}_{2}$ secretion noted after the highest $\mathrm{Cd}$ dose may contribute to the prolongation of the diestrus stage in the estrous cycle. Such observations are in line with our previous results from a 30-day experiment [24] and studies conducted by Samuel et al. [29]. Disorders in the cycle may be the first symptoms of reproductive aging [53]. This can be indirectly confirmed by decreased thickness of the epithelial endometrium observed in our study, which significantly correlated with a lowered concentration of $\mathrm{E}_{2}$ in the plasma.
It is suggested that estradiol is a physiological antioxidant whose deficiency has been shown to be associated with oxidative stress [54]. Thus, the changes observed in the uterus of rats receiving high doses of $\mathrm{Cd}$ in this study may also be associated with the induction of oxidative stress in the reproductive organs and it cannot be ruled out that the induction of oxidative stress contributes to changes in hormonal balance. The mechanism of prooxidative Cd action is well known [55]. Although Cd is not a redox-active agent and is not able to directly generate ROS through the Fenton or Haber-Weiss reaction, it contributes to the occurrence of oxidative stress indirectly through weakening the antioxidative defence and increasing prooxidant concentrations, as well as causing mitochondria injury [56]. Numerous in vitro and in vivo studies confirmed that $\mathrm{Cd}$ disrupts the antioxidant defence by reducing the levels of antioxidants, which are important in the removal of ROS [55,57]. Effects of ROS can be mitigated by antioxidants, both nonenzymatic and enzymatic, and key enzymatic antioxidants in cells are superoxide dismutase (SOD), catalase (CAT), and glutathione peroxidase 
(GPx) $[58,59]$. CAT plays a crucial role in scavenging peroxides such as $\mathrm{H}_{2} \mathrm{O}_{2}$. Thus, its diminished activity may indicate cellular accumulation of this reactive oxygen species, which are capable of crossing cell membranes [58]. Although subacute (up to 30 days) administration of Cd leads to alterations in enzymatic antioxidant defence in rat uteri and ovaries $[29,31,60-62]$, there is no data concerning subchronic $\mathrm{Cd}$ exposure. In the present subchronic study, decreased CAT activity and increased MDA concentration caused by the highest $\mathrm{Cd}$ dose seem to confirm disturbed redox balance in the uterus. Although other markers of oxidative stress were not determined, it could be assumed that the decrease of CAT activity may indicate an oxidative stress in this tissue.

It was reported that ROS may propagate the initial attack on lipid membranes to cause lipid peroxidation (LPO). MDA (malondialdehyde) is one of the numerous compounds formed during the process of LPO, which binds to, inter alia, proteins and DNA modifying its structure. Studies proved that these MDA adducts play a critical role in many cellular processes and may participate in secondary deleterious reactions that may cause profound changes in the biochemical properties of biomolecules, which may facilitate development of various pathological states [63]. The significantly increased MDA concentration in uterine tissue, which was observed in this study, remained up to six months after terminating the exposure. Thus, the histopathological changes in the uterus may be also the result of the indirect induction of lipid peroxidation by $\mathrm{Cd}$.

Noteworthy, Cd could induce ROS production also nonenzymatically. Nonenzymatic antioxidants such as vitamins $\mathrm{C}$ and $\mathrm{E}$, zinc and selenium, protein thiols (e.g., glutathione), bilirubin, and urate are often determined as total antioxidant status (TAS). In this study, the uterine concentration of GSH and plasma TAS in rats exposed to $\mathrm{Cd}$ did not differ significantly from that of control rats. Also, Mężyńska et al. [44, 64] did not observe a statistically significant difference in TAS concentrations analyzed in rat liver after a similar time (3 month) and level of Cd exposure (1 and $5 \mathrm{mg} / \mathrm{kg}$ b.w.). A significantly reduced hepatic TAS concentration was noticed only after ten months of Cd administration $[44,64]$. Therefore, it has been suggested that the mechanism of oxidative stress induced by Cd may vary and depend on the time of exposure. Some studies indicate that chronic exposure to Cd probably induces ROS by overwhelming the antioxidant defence leading to increased lipid peroxidation $[64,65]$. On the other hand, short-term exposure to $\mathrm{Cd}$ contributes to a significant depletion of glutathione and protein-bound sulfhydryl groups, which results in enhanced production of ROS $[66,67]$.

Unfortunately, it is very difficult to state whether $\mathrm{Cd}$ can affect reproduction in women through changes in sex hormones and/or through oxidative stress. So far, it has only been shown that $\mathrm{Cd}$ accumulates in women's uteri and it may also be responsible for impaired hormonal metabolism [10, 68-72]. Moreover, in several epidemiological studies, the relationship between dietary $\mathrm{Cd}$ exposure and incidence of hormone-related cancer, including in the endometrium and ovaries, has been observed $[11,73]$.

\section{Conclusions}

Our study indicates that Cd exhibits both estrogenic-like (in a low dose range) and antiestrogenic-like (in a high dose range) effects, which were connected with disturbed plasma and the uterine estradiol concentrations and estrous cyclicity disorders. These effects, as well as increased lipid peroxidation in the uterus and ovary, were observed for six months following termination of $\mathrm{Cd}$ exposure. In addition, Cd toxicity after the highest dose was also associated with structural damage of the uterus and ovaries. The obtained results indicate that women's long-term exposure to $\mathrm{Cd}$ may lead to reproductive system disorders, which might even result in infertility.

\section{Data Availability}

The data used to support the findings of this study are included within the article.

\section{Conflicts of Interest}

The authors declare that there is no conflict of interest regarding the publication of this paper.

\section{Acknowledgments}

This work was supported by the Polish National Science Centre (Grant No. N404 504938). The authors would like to thank Małgorzata Skrzypińska-Gawrysiak, Ph.D., and Krystyna Sitarek, Ph.D., for their helpful advice on various technical issues and Anna Jurek, M.A., for comments and suggestions during the preparation of the English version of this paper.

\section{Supplementary Materials}

The supplemental information provides additional data concerning organs and body weights of rats after oral exposure to $\mathrm{CdCl}_{2}$ or $17 \beta$-estradiol (positive control) and 90 and 180 -day postexposure periods in comparison to controls (Tables S1 and S2). Moreover, Figures S1, S2, and S3 depict the estrous cycle in single females after all periods of exposure to $\mathrm{Cd}$ or $17 \beta$-estradiol as well as in observation periods. (Supplementary Materials)

\section{References}

[1] ATSDR, Agency for Toxic Substances and Disease Registry, ATSDR's Substance Priority List, 2017, https://www.atsdr.cdc .gov/spl/index.html.

[2] G. F. Nordberg, A. Bernard, G. L. Diamond et al., "Risk assessment of effects of cadmium on human health (IUPAC Technical Report)," Pure and Applied Chemistry, vol. 90, no. 4, pp. 755-808, 2018.

[3] L. Järup and A. Åkesson, "Current status of cadmium as an environmental health problem," Toxicology and Applied Pharmacology, vol. 238, no. 3, pp. 201-208, 2009. 
[4] EFSA, European Food Safety Authority, "Cadmium dietary exposure in the European population," EFSA Journal, vol. 10, no. 1, pp. 2551-2588, 2012.

[5] EFSA, European Food Safety Authority, "Cadmium in food, scientific opinion of the panel on contaminants in the food chain,” The EFSA Journal, vol. 980, pp. 1-139, 2009.

[6] M. Vahter, M. Berglund, A. Åkesson, and C. Lidén, "Metals and women's health," Environmental Research, vol. 88, no. 3, pp. 145-155, 2002.

[7] S. Satarug, J. R. Baker, P. E. B. Reilly, M. R. Moore, and D. J. Williams, "Cadmium levels in the lung, liver, kidney cortex, and urine samples from Australians without occupational exposure to metals," Archives of Environmental Health: an International Journal, vol. 57, no. 1, pp. 69-77, 2002.

[8] S. Satarug and M. R. Moore, "Adverse health effects of chronic exposure to low-level cadmium in foodstuffs and cigarette smoke," Environmental Health Perspectives, vol. 112, no. 10, pp. 1099-1103, 2004.

[9] M. Uetani, E. Kobayashi, Y. Suwazono, T. Kido, and K. Nogawa, "Cadmium exposure aggravates mortality more in women than in men," International Journal of Environmental Health Research, vol. 16, no. 4, pp. 273-279, 2006.

[10] M. Nasiadek, T. Krawczyk, and A. Sapota, "Tissue levels of cadmium and trace elements in patients with myoma and uterine cancer," Human and Experimental Toxicology, vol. 24, no. 12, pp. 623-630, 2005.

[11] A. Åkesson, B. Julin, and A. Wolk, "Long-term dietary cadmium intake and postmenopausal endometrial cancer incidence: a population-based prospective cohort study," Cancer Research, vol. 68, no. 15, pp. 6435-6441, 2008.

[12] P. Rzymski, P. Niedzielski, P. Rzymski, K. Tomczyk, L. Kozak, and B. Poniedziałek, "Metal accumulation in the human uterus varies by pathology and smoking status," Fertility and Sterility, vol. 105, no. 6, pp. 1511-1518.e3, 2016.

[13] K. Paksy, B. Varga, and P. Lázár, "Cadmium interferes with steroid biosynthesis in rat granulosa and luteal cells in vitro," Biometals, vol. 5, no. 4, pp. 245-250, 1992.

[14] P. Massányi and V. Uhrín, "Histological changes in the uterus of rabbits after an administration of cadmium," Journal of Environmental Science and Health. Part A: Environmental Science and Engineering and Toxicology, vol. 32, no. 5, pp. 14591466, 1997.

[15] M. P. Waalkes and S. Rehm, "Lack of carcinogenicity of cadmium chloride in female Syrian hamsters," Toxicology, vol. 126, no. 3, pp. 173-178, 1998.

[16] M. Piasek and J. W. Laskey, "Effects of in vitro cadmium exposure on ovarian steroidogenesis in rats," Journal of Applied Toxicology, vol. 19, no. 3, pp. 211-217, 1999.

[17] D. Tomislav, D. Vesna, T. Antun, C. Marijan, B. Ljiljana, and M. Darko, "The effect of cadmium salts on plasma hormone levels and histopathology of the ovaries in female rabbits," Tieraerztliche Umschau, vol. 57, no. 10, pp. 539-546, 2002.

[18] X. Y. Han, Z. R. Xu, Y. Z. Wang, and W. L. Du, "Effects of cadmium on serum sex hormone levels in pigs," Journal of Animal Physiology and Animal Nutrition, vol. 90, no. 9-10, pp. 380384, 2006.

[19] W. Zhang and H. Jia, "Effect and mechanism of cadmium on the progesterone synthesis of ovaries," Toxicology, vol. 239, no. 3, pp. 204-212, 2007.
[20] P. Massányi, N. Lukáč, V. Uhrín et al., "Female reproductive toxicology of cadmium," Acta Biologica Hungarica, vol. 58, no. 3, pp. 287-299, 2007.

[21] N. Höfer, P. Diel, J. Wittsiepe, M. Wilhelm, and G. H. Degen, "Dose- and route-dependent hormonal activity of the metalloestrogen cadmium in the rat uterus," Toxicology Letters, vol. 191, no. 2-3, pp. 123-131, 2009.

[22] A. W. Obianime and J. S. Aprioku, "Biochemical and hormonal effects of cadmium in female guinea pigs," Journal of Toxicology and Environmental Health Sciences, vol. 3, no. 2, pp. 39-43, 2011.

[23] M. Monsefi and B. Fereydouni, "The effects of cadmium pollution on female rat reproductive system," Journal of Infertility and Reproductive Biology, vol. 1, no. 1, pp. 1-6, 2013.

[24] M. Nasiadek, M. Danilewicz, K. Sitarek et al., "The effect of repeated cadmium oral exposure on the level of sex hormones, estrous cyclicity, and endometrium morphometry in female rats," Environmental Science and Pollution Research International, vol. 25, no. 28, pp. 28025-28038, 2018.

[25] A. Stoica, B. S. Katzenellenbogen, and M. B. Martin, "Activation of estrogen receptor-alpha by the heavy metal cadmium," Molecular Endocrinology, vol. 14, no. 4, pp. 545-553, 2000.

[26] M. D. Johnson, N. Kenney, A. Stoica et al., "Cadmium mimics the in vivo effects of estrogen in the uterus and mammary gland," Natural Medicine, vol. 9, no. 8, pp. 1081-1084, 2003.

[27] I. Ali, P. E. Penttinen-Damdimopoulou, S. I. Mäkelä et al., "Estrogen-Like Effects of Cadmium in Vivo Do Not Appear to be Mediated via the Classical Estrogen Receptor Transcriptional Pathway," Environmental Health Perspectives, vol. 118, no. 10, pp. 1389-1394, 2010.

[28] Y. Wang, X. Wang, Y. Wang et al., "Effect of cadmium on cellular ultrastructure in mouse ovary," Ultrastructural Pathology, vol. 39, no. 5, pp. 324-328, 2015.

[29] J. B. Samuel, J. A. Stanley, R. A. Princess, P. Shanthi, and M. S. Sebastian, "Gestational cadmium exposure-induced ovotoxicity delays puberty through oxidative stress and impaired steroid hormone levels," Journal of Medical Toxicology: Official Journal of the American College of Medical Toxicology, vol. 7, no. 3, pp. 195-204, 2011.

[30] P. Massányi, V. Uhrín, and M. Valent, "Correlation relationship between cadmium accumulation and histological structures of ovary and uterus in rabbits," Journal of Environmental Science and Health. Part A: Environmental Science and Engineering and Toxicology, vol. 32, no. 5, pp. 1621-1635, 1997.

[31] M. Nasiadek, M. Skrzypińska-Gawrysiak, A. Daragó, E. Zwierzyńska, and A. Kilanowicz, "Involvement of oxidative stress in the mechanism of cadmium-induced toxicity on rat uterus," Environmental Toxicology and Pharmacology, vol. 38, no. 2, pp. 364-373, 2014.

[32] A. J. Lehman, "Chemicals in foods: a report to the association of food and drug officials on current developments. Part II. Pesticides," Association of Food and Drug Officials - Quarterly Bulletin, vol. 15, pp. 122-125, 1951.

[33] Organisation for Economic Co-operation and Development (OECD), "Guidance Document for Histologic Evaluation of Endocrine and Reproductive Tests in Rodents. Part 5: Preparation, Reading and Reporting of Vaginal Smears," Series on testing and assessment, 2009. 
[34] R. Fox and C. Laird, "Sexual cycles," in Reproduction and Breeding Techniques for Laboratory Animals, E. S. E. Hafez, Ed., pp. 107-122, Lee and Febiger, Philadelphia, 1970.

[35] O. H. Lowry, N. J. Rosebrough, A. L. Farr, and R. J. Randall, "Protein measurement with the Folin phenol reagent," The Journal of Biological Chemistry, vol. 193, no. 1, pp. 265-275, 1951.

[36] J. Sedlak and R. H. Lindsay, "Estimation of total, proteinbound, and nonprotein sulfhydryl groups in tissue with Ellman's reagent," Analytical Biochemistry, vol. 25, no. 1, pp. 192-205, 1968.

[37] A. Meister, "Glutathione metabolism and its selective modification," The Journal of Biological Chemistry, vol. 263, no. 33, pp. 17205-17208, 1988.

[38] S. C. Lu, "Regulation of glutathione synthesis," Molecular Aspects of Medicine, vol. 30, no. 1-2, pp. 42-59, 2009.

[39] M. Uchiyama and M. Mihara, "Determination of malonaldehyde precursor in tissues by thiobarbituric acid test," Analytical Biochemistry, vol. 86, no. 1, pp. 271-278, 1978.

[40] M. Brama, L. Gnessi, S. Basciani et al., "Cadmium induces mitogenic signaling in breast cancer cell by an ER $\alpha$-dependent mechanism," Molecular and Cellular Endocrinology, vol. 264, no. 1-2, pp. 102-108, 2007.

[41] E. Silva, M. J. Lopez-Espinosa, J. M. Molina-Molina, M. Fernández, N. Olea, and A. Kortenkamp, "Lack of activity of cadmium in in vitro estrogenicity assays," Toxicology and Applied Pharmacology, vol. 216, no. 1, pp. 20-28, 2006.

[42] C. V. Rider, P. C. Hartig, M. C. Cardon, and V. S. Wilson, "Comparison of chemical binding to recombinant fathead minnow and human estrogen receptors alpha in whole cell and cell-free binding assays," Environmental Toxicology and Chemistry, vol. 28, no. 10, pp. 2175-2181, 2009.

[43] D. Wang, H. Sun, Y. Wu et al., "Tubular and glomerular kidney effects in the Chinese general population with low environmental cadmium exposure," Chemosphere, vol. 147, pp. 3-8, 2016.

[44] M. Mężyńska, M. Brzóska, J. Rogalska, and B. Piłat-Marcinkiewicz, "Extract from Aronia melanocarpa L. berries prevents cadmium-induced oxidative stress in the liver: a study in a rat model of low-level and moderate lifetime human exposure to this toxic metal," Nutrients, vol. 11, no. 1, p. 21, 2018.

[45] G. Nordberg, T. Jin, A. Bernard et al., "Low bone density and renal dysfunction following environmental cadmium exposure in China," AMBIO: A Journal of the Human Environment, vol. 31, no. 6, pp. 478-481, 2002.

[46] M. Nasiadek, E. Swiatkowska, A. Nowinska, T. Krawczyk, J. R. Wilczynski, and A. Sapota, "The effect of cadmium on steroid hormones and their receptors in women with uterine myomas," Archives of Environmental Contamination and Toxicology, vol. 60, no. 4, pp. 734-741, 2011.

[47] OECD, Organization for Economic Co-operation and Development, Guidelines for the Testing of Chemicals. Test no 440. Uterotrophic Bioassay in Rodents: A Short-Term Screening Test for Oestrogenic Properties, ENV/EPOC, Paris OCD, 2007.

[48] P. Diel, S. Schmidt, and G. Vollmer, "In vivo test systems for the quantitative and qualitative analysis of the biological activity of phytoestrogens," Journal of Chromatography. B, Analytical Technologies in the Biomedical and Life Sciences, vol. 777, no. 1-2, pp. 191-202, 2002.
[49] W. Zhang, J. Yang, J. Wang et al., "Comparative studies on the increase of uterine weight and related mechanisms of cadmium and p-nonylphenol," Toxicology, vol. 241, no. 1-2, pp. 84-91, 2007.

[50] P. Fechner, P. Damdimopoulou, and G. Gauglitz, "Biosensors paving the way to understanding the interaction between cadmium and the estrogen receptor alpha," PLOS ONE, vol. 6, no. 8, article e23048, 2011.

[51] F. M. Kluxen, N. Höfer, G. Kretzschmar, G. H. Degen, and P. Diel, "Cadmium modulates expression of aryl hydrocarbon receptor-associated genes in rat uterus by interaction with the estrogen receptor," Archives of Toxicology, vol. 86, no. 4, pp. 591-601, 2012.

[52] X. Denier, E. M. Hill, J. Rotchell, and C. Minier, "Estrogenic activity of cadmium, copper and zinc in the yeast estrogen screen," Toxicology In Vitro, vol. 23, no. 4, pp. 569-573, 2009.

[53] J. M. Goldman, A. S. Murr, and R. L. Cooper, "The rodent estrous cycle: characterization of vaginal cytology and its utility in toxicological studies," Birth Defects Research (Part B), vol. 80, no. 2, pp. 84-97, 2007.

[54] T. Sugiyama, H. Minoura, N. Kawabe, M. Tanaka, and K. Nakashima, "Preferential expression of long form prolactin receptor mRNA in the rat brain during the oestrous cycle, pregnancy and lactation: hormones involved in its gene expression," The Journal of Endocrinology, vol. 141, no. 2, pp. 325-333, 1994.

[55] M. Jurczuk, M. M. Brzóska, J. Moniuszko-Jakoniuk, M. Gałażyn-Sidorczuk, and E. Kulikowska-Karpińska, "Antioxidant enzymes activity and lipid peroxidation in liver and kidney of rats exposed to cadmium and ethanol," Food and Chemical Toxicology, vol. 42, no. 3, pp. 429-438, 2004.

[56] J. Zhang, Y. Wang, L. Fu et al., "Subchronic cadmium exposure upregulates the mRNA level of genes associated to hepatic lipid metabolism in adult female CD1 mice," Journal of Applied Toxicology, vol. 38, no. 7, pp. 1026-1035, 2018.

[57] S. Sarkar, P. Yadav, and D. Bhatnagar, "Lipid peroxidative damage on cadmium exposure and alterations in antioxidant system in rat erythrocytes: a study with relation to time," Biometals, vol. 11, no. 2, pp. 153-157, 1998.

[58] L. He, T. He, S. Farrar, L. Ji, T. Liu, and X. Ma, “Antioxidants maintain cellular redox homeostasis by elimination of reactive oxygen species," Cellular Physiology and Biochemistry, vol. 44, no. 2, pp. 532-553, 2017.

[59] S. Mendes, F. Timóteo-Ferreira, H. Almeida, and E. Silva, "New insights into the process of placentation and the role of oxidative uterine microenvironment," Oxidative Medicine and Cellular Longevity, vol. 2019, Article ID 9174521, 18 pages, 2019.

[60] V. U. Nna, U. Z. Usman, E. O. Ofutet, and D. U. Owu, "Quercetin exerts preventive, ameliorative and prophylactic effects on cadmium chloride-induced oxidative stress in the uterus and ovaries of female Wistar rats," Food and Chemical Toxicology, vol. 102, pp. 143-155, 2017.

[61] L. P. Nampoothiri, A. Agarwal, and S. Gupta, "Effect of coexposure to lead and cadmium on antioxidant status in rat ovarian granulose cells," Archives of Toxicology, vol. 81, no. 3, pp. 145-150, 2007.

[62] D. Roopha and P. Latha, "Cadmium exposure-induced oxidative stress; delay in sexual maturation and impaired hormones in developing rat ovary," Oxidants and Antioxidants in Medical Science, vol. 2, no. 3, pp. 181-187, 2013. 
[63] A. Ayala, M. F. Muñoz, and S. Argüelles, "Lipid Peroxidation: Production, Metabolism, and Signaling Mechanisms of Malondialdehyde and 4-Hydroxy-2-Nonenal," Oxidative Medicine and Cellular Longevity, vol. 2014, Article ID 360438, 31 pages, 2014.

[64] M. Mężyńska, M. Brzóska, J. Rogalska, and A. Galicka, "Extract from Aronia melanocarpa L. berries protects against cadmium-induced lipid peroxidation and oxidative damage to proteins and DNA in the liver: a study using a rat model of environmental human exposure to this xenobiotic," Nutrients, vol. 11, no. 4, p. 758, 2019.

[65] M. Waisberg, P. Joseph, B. Hale, and D. Beyersmann, "Molecular and cellular mechanisms of cadmium carcinogenesis," Toxicology, vol. 192, no. 2-3, pp. 95-117, 2003.

[66] F. Liu and K.-Y. Jan, "DNA damage in arsenite- and cadmiumtreated bovine aortic endothelial cells," Free Radical Biology and Medicine, vol. 28, no. 1, pp. 55-63, 2000.

[67] M. Andjelkovic, A. B. Djordjevic, E. Antonijevic et al., "Toxic effect of acute cadmium and lead exposure in rat blood, liver, and kidney," International Journal of Environmental Research and Public Health, vol. 16, no. 2, p. 274, 2019.

[68] C. Nagata, Y. Nagao, C. Shibuya, Y. Kashiki, and H. Shimizu, "Urinary cadmium and serum levels of estrogens and androgens in postmenopausal Japanese women," Cancer Epidemiology, Biomarkers \& Prevention: A Publication of the American Association for Cancer Research, cosponsored by the American Society of Preventive Oncology, vol. 14, no. 3, pp. 705-708, 2005.

[69] C. M. Gallagher, B. S. Moonga, and J. S. Kovach, "Cadmium, follicle-stimulating hormone, and effects on bone in women age 42-60 years, NHANES III," Environmental Research, vol. 110, no. 1, pp. 105-111, 2010.

[70] A. Z. Pollack, E. F. Schisterman, L. R. Goldman et al., "Cadmium, lead, and mercury in relation to reproductive hormones and anovulation in premenopausal women," Environmental Health Perspectives, vol. 119, no. 8, pp. 1156-1161, 2011.

[71] L. W. Jackson, P. P. Howards, J. Wactawski-Wende, and E. F. Schisterman, "The association between cadmium, lead and mercury blood levels and reproductive hormones among healthy, premenopausal women," Human Reproduction, vol. 26, no. 10, pp. 2887-2895, 2011.

[72] I. Ali, A. Engström, M. Vahter et al., "Associations between cadmium exposure and circulating levels of sex hormones in postmenopausal women," Environmental Research, vol. 134, pp. 265-269, 2014.

[73] B. Julin, A. Wolk, and A. Åkesson, "Dietary cadmium exposure and risk of epithelial ovarian cancer in a prospective cohort of Swedish women," British Journal of Cancer, vol. 105, no. 3, pp. 441-444, 2011. 


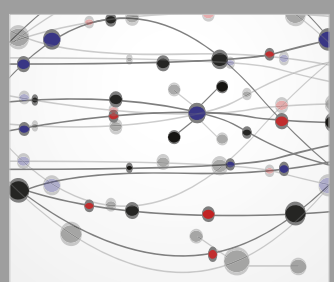

The Scientific World Journal
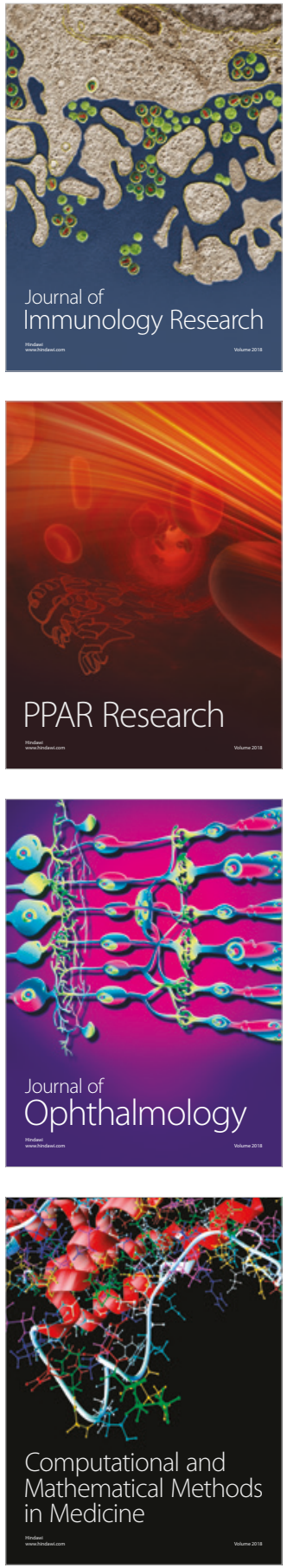

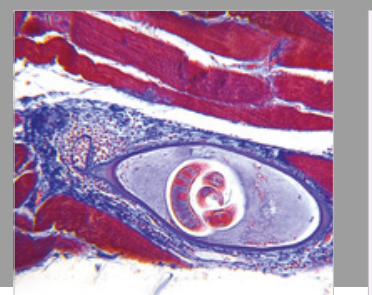

Gastroenterology Research and Practice



\section{Hindawi}

Submit your manuscripts at

www.hindawi.com




ournal of

Diabetes Research

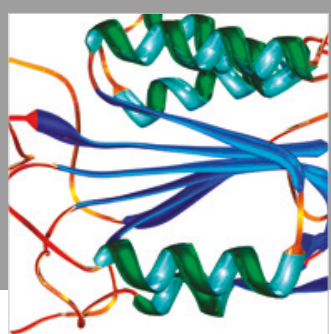

Disease Markers
